\title{
The Linkage Between Capital Formation And Capacity Utilization Of Manufacturing Sector In Nigeria.
}

\author{
${ }^{1}$ Atoyebi Kehinde .O., ${ }^{2}$ Ishola .S. Ademola, ${ }^{3}$ Adekunjo Felix. O., \\ ${ }^{4}$ Kadiri Kayode .I.,${ }^{5}$ Ogundeji Musibau .O. \\ ${ }^{1}$ Lagos State University, Ojo Department Of Economics \\ ${ }^{2}$ Head, Internal Control \& Audit Energy Group Of Companies \\ ${ }^{3}$ Lagos State University, Ojo Department Of Economics \\ ${ }^{4}$ Lagos State University, Ojo Department of Economics \\ ${ }^{5}$ Lagos State University, Ojo Depatment of Economics
}

\begin{abstract}
This study seeks to determine the linkage between capital formation and capacity utilization rate of the manufacturing sector in Nigeria using annual data from 1981 to 2009. In our empirical analysis, we run an ordinary least square test to verify the statistical significance of the variables used and augmented form of granger causality test to identify the direction of the relationship between this variables in the long run. Empirical investigations revealed that only one variable is statistically significant at 5\% and this variable is gross fixed capital formation. However, this variable is negatively related to average capacity utilization rate, in which case is not in conformity with a prior expectation which is justified by is co-efficient value of -0.14, which implies that a unit increase in capital formation to the manufacturing sector, will decrease average capacity utilization by $14 \%$.

Our findings based on granger causality test suggest the existence of uni-direction causal relationship between average capacity utilization rate and capital formation with the direction from capital formation. There is an existence of a bi-direction relationship between average capacity utilization and gross domestic product.

Based on our findings, the study therefore recommends that Nigeria government should encourage capital formation via commercial banks to reduce the interest rate on loans and advances that will encourage more investment in manufacturing sector with absolute monitoring by the commercial banks to save the loans from being diverted from its main purpose.
\end{abstract}

Key words: Capital formation, Capacity utilization, Manufacturing sector and Commercial bank credit.

\section{Introduction}

Capital formation has been broadly defined as the increase in physical capital stock of a nation with investment in social and economic infrastructure.

It is has been argued that manufacturing capacity of industries in Nigeria may be investigated through the study of such vital indices of growth value added, capital formation in the sector, coverage of products industralised and changes in trade structure. A mere look at the concentrations of industries in urban centres in Nigeria may give a misleading information of a high state of industrialization in Nigeria. A country like Nigeria need to be indsutrlised to achieve rapid economic and social development.

Arguably, modern manufacturing processes are characterized by high technological innovations, management and entrepreneurial talents and improvements in technical skills which could enhance productivity and better living conditions. And on this note successive government in Nigeria have adopted certain measures and programme to achieve industrial growth and development. This cannot be achieve until manufacturing capacity is utilized to a reasonable level.

Fabayo (1982) defined capacity under utilization as a phenomenon which on industry is unable to full utilize its installed scale of plant on a sustainable basis. The manufacturing capacity utilization in the late 4970s was as high as 78.70 percent and declined as low as 43.80 percent in the 1980s. Between 2000 and 2005, it oscillated around 34.60 and 52.78 percent. The manufacturing value added and employment generation which were also determinants of industrial development, oscillated within the same period.

The were as a resulting infrastructural inadequacies and low incentives put in place to boost manufacturing productivity in Nigeria. Ayodell and Fatokun (2005), asserted that the introduction of the Structural and Adjustment Programme (SAP) was tailored to ameliorate the problem rather aggravated it as experienced through a regime of high inflation rate which makes domestic manufacturer's and domestic market uncompetitive.

In the light of this background, the paper aims at examining the linkage between capital formation and capacity utilization in Nigeria manufacturing sector. 
The rest of the study as structured as follow. Section 2 reviews selected existing literature. Section 3 gives the stylized facts about capacity utilization in manufacturing sector in Nigeria.

\section{Selected Existing Literature}

Detailed and historical validation has provided empirical evidence on the toward state of capacity utilization in the Nigeria manufacturing sector role of capital formation.

In a study by Rankin et al (2001), he observed that when there was boom in oil prices during the 1970s, the country neglected other sectors like manufacturing, agriculture, mining etc. This was because the country was earning enough from crude oil exports that could have been used to develop other sectors. There were also other factors that precipitated the decline of manufacturing sector. For example, from 1970 to 2005, foreign investors through express interest in the manufacturing business in Nigeria such as steel, wood, food, electronics chemicals and others but regulations and other restrictions impede such interest.

Ledes (2009) studied the economic conditions of Nigeria and observed that since Nigeria is one of the least industrialized countries of the sub-Saharah AFRICA region, this reflect from its varying levels of negligence on those sectors mentioned which also lead to the collapse of the countries basic infrastructure as well as its social services in 1980 s.

Ata (2002) summed the economic condition in Nigeria by identifying some of the factors that hinders manufacturing growth in Nigeria. These factors include inadequate finance, insecurity, market distorting, state owed monopolies etc.

Adenilanju and Chete (2003) conducted on empirical analysis of the performance of the Nigeria manufacturing sector over a 30 - year period and observed that the sector was performing with satisfactory growth levels from 1970 - 1980. But, between 1980 and 2007. The Nigeria manufacturing subsector recorded a systematic decline in capacity utilization by about a total of 485,000 that is, from 948,000 units of bicycles in 1977 to 161,500 units of bicycles in 2007.

Adejugbe (2004) examine the impact of the Nigerian trade policy on the manufacturing performance of Nigeria and observed that some significant steps were taken by the Nigeria government to make the trade regime liberal, but the adaptation of flexible exchange rate mechanism, along with some other liberalization policies brought some major changes to the scenario as these steps helps reduce tariffs and trade rates.

Anyawu (2005), with findings similar to that of Adenikinju and Chete observed that the world oil market in the early 1980s and the prolonged economic recession which lead to a sharp fall in foreign exchange earnings of Nigeria further led to a fall in the performance level of the manufacturing sector in the country.

In another study conducted by (7) Chete and Adenikinju in (1989), they observed that the overall productivity level of the Nigerian manufacturing sector over the years has see very little increase and most of these companies have even, faced a decline in productivity as well as profitability.

Ayanwale (2002) studies the effect of foreign direct investment on the performance of the manufacturing sector in Nigeria and observed that the available statistics of the Nigeria's manufacturing and macro economics data does not paunt a good picture of manufacturing contributions to GDP and natural employment.

For example, manufacturing contribution to DP has been below $10 \%$ between 1990 and 2005 with the expectation that it will reach $15 \%$ by 2010 .

In a survey report from the United Industrial Development Organization (UNDO), Malik et al (2001) observes that Nigerian manufacturing sector has been working with mostly unskilled and unqualified labour which in turn affects the quality of the manufacturing products in Nigeria.

Alli (2009) reviewed the more current performance of the Nigeria manufacturing sector by surveying the result of a study conducted in 2007 by the Manufacturer Association of Nigeria (MAN). The report discovered that only a meagre percentage of manufacturing companies $(10 \%)$ are operating at a sustainable level, whereas as much as $60 \%$ are going to shut down due to series of financial and other kinds of cries. Other factors such as "high production costs caused by energy, high interest and exchange rates, influx of inferior and substandard products from other nations, multiplicity of taxes and levies, poor sales as a result of low purchasing power of the consumes etc.

Dipak and Ata (2008) argue that the main problems facing the Nigerian manufacturing sector are the ongoing advancements in technology at the international level. They observed that research and development work is not being done at a good enough level for the constituents to ever see a steady growth in the performance of manufacturing sectors.

Ojowu (2003), with his analysis of the situation of the Nigeria manufacturing sector, concluded that capacity utilization is an important issues. The issues associated with capacity utilization such as capacity decline capacity expansion and capacity mortality are germane in bringing the quality into the performance of the Nigerian manufacturing sector. 
Enebong (2004) predicts the level of the Nigerian manufacturing sector performance that it well continue experiencing a decline due to the inability of the manufacturer to accessing raw materials as a result of stiff competition from foreign firms.

He theorizes that many of the policies implemented by the government in the late 1990s are still acting as barriers to manufacturing sector growth. Some of there policies include backward integration and inward orientation strategies towards import substitution.

Alos (2007) analysed then business environment of Nigeria and observed that the performance of the manufacturing sector has been very uncertain, even nearly chaotic for many years. He also observed that in the manufacturing sector there is gross underlitilization of resources and only $30 \%$ to $40 \%$ of the capital is being utilized in this sector due to "frequent power outages, lack of funds to procure inputs, fall in demand for manufactured goods and frequent strikes and lockouts by workers and their employers.

Okejiri (2008) posited that one of the largest constraints for the high productivity of the Nigeria is manufacturing sector is, again, the low level of technology, as advancements in technology are changing the manufacturing sectors of countries all over the world.

A study conducted by Havryly Shgn (2001) posited that some of the major problems that acts as barriers to high quality growth performance in the Nigeria manufacturing sector. This include investors in the manufacturing sector often lack a business friendly environment.

Talabi (2003) argued that the problems associated with the decimal performance of Nigerian manufacturing sectors are the bye-products of policies and strategies that have been in practice for many years. There is need for the government to focus upon the formulation often equipment leasing law that will work to improve these weak infrastructure of the country. If this is implemented, inturn the manufacturers will be encouraged to manufacturer high quality products.

The political imbroglio of the period, inconsistent government policies, corruption, increasing cost of raw materials, poor infrastructures, shortage of petroleum products, ineffective demand for local manufacturers are reasons capacity utilization have been decreasing steadily. Also, in competitiveness of Nigeria product bottleneck and other structured rigidity are problems facing manufacturing industries in their capacity formation and capacity utilization efforts.

\section{The Nigerian Manufacturing Sector}

\section{Stylized Facts}

Manufacturing is one of the faster growing sectors of the Nigerian economy being second to the mining sector. However, the manufacturing sectors contribution to the Gross Domestic Product is minimal, hence; the percentage share of manufacturing output to Gross Domestic Product is small.

Taking the following data on Gross Domestic Product, Gross Domestic Product at current factor costs for manufacturing and percentage distribution (1989-2009).

\begin{tabular}{|l|l|l|l|l|}
\hline Year & $\begin{array}{l}\text { Manufacturing } \\
\text { GDP (N.M) }\end{array}$ & $\begin{array}{l}\text { Gross Domestic } \\
\text { Product (N'm) }\end{array}$ & $\begin{array}{l}\text { Percentage } \\
\text { distribution } \\
\text { (Manufacture) }\end{array}$ & Percentage change \\
\hline 1989 & 11774.72 & 222457.60 & 5.29 & - \\
\hline 1990 & 14296.64 & 25787.03 & 5.90 & 4.73 \\
\hline 1991 & 18892.08 & 320247.34 & 5.90 & 6.3 \\
\hline 1992 & 26348.53 & 544330.68 & 4.84 & -17.9 \\
\hline 1993 & 38430.8 & 695986.05 & 5.52 & 14.0 \\
\hline 1994 & 69296.52 & 911068.01 & 6.91 & 25.2 \\
\hline 1995 & 105153.50 & 1960685.58 & & -22.4 \\
\hline 1996 & 132554.26 & 2740458.49 & 4.84 & -9.7 \\
\hline 1998 & 144106.95 & 2834998.49 & 5.08 & 5.0 \\
\hline 1999 & 142226.05 & 2765671.39 & 5.15 & 1.4 \\
\hline 2000 & 147156.71 & 2817671.21 & 4.72 & 22.1 \\
\hline 2001 & 187157.8 & 2932172.11 & 4.81 & 15.1 \\
\hline 2002 & 215717.1 & 3017671.4 & 4.37 & 22.3 \\
\hline 2003 & 317878.7 & 3217371.71 & 3.79 & 11.7 \\
\hline 2004 & 457817.3 & 3717871.32 & 5.10 & 15.7 \\
\hline 2005 & 417871.1 & 3872142.4 & 6.32 & 16.3 \\
\hline 2006 & 401171.3 & 4017182.2 & 5.35 & 16.8 \\
\hline 2007 & 517372.1 & 4111712.2 & 5.21 & 15.1 \\
\hline 2008 & 50717.2 & 5231721.1 & 4.21 & 4.7 \\
\hline 2009 & 63175.4 & 5378723.4 & 6.38 & 2.8 \\
\hline
\end{tabular}


Annual average rate of manufacturing $(\mathrm{GDP})=0.8 \%$.

The contribution of the manufacturing sector to Gross Domestic Product rise at an annual average rate of $0.8 \%$ between 1989 and 2009. In absolute terms, the contribution of the manufacturing sector to Gross Domestic Product decreased from 5.29\% in 1989 to 6.42 in 2009.

Specifically, the manufacturing sector contribution rate to the Gross Domestic Product increased between 1989 and 1990, from a rate of $5.29 \%$ to $5.54 \%$. Also, the rate increased to $5.9 \%$ in 1991 but, task a plunge of about $18 \%$ in 1992, moreso, it also move to $2.8 \%$ in 2009 due to poor energy supply, which could inconsistent government policies, corruption, increasing cost of raw materials, poor infrastructure, shortage of petroleum products, ineffective demand for local manufactures occasioned bar low purchasing power on the hand and the influx of cheaper product into the country on the other hand.

In 1993, and 1994, the manufacturing sector's contribution rate to Gross Domestic Product increased to $5.52 \%$ and $5.91 \%$ respectively. This is attributable to improve policies of government to financing mediumsized enterprise.

However, in 1995 and 1996, the manufacturing sector's contribution rate to domestic product increased to $5.08 \%$ and $5.15 \%$ respectively.

Nevertheless, compassion of the average contribution rate of manufacturing to the gross domestic product between 1989 and 2009 shows that the manufacturing sector needs to be urgently attended to. As a matter of urgency, realistic and innovative idea on how to make infrastructure work, such as privatization and other port reforms and the removal of other bottlenecks to investments in the manufacturing sector should be embarked upon to improve the level of sophistication and development.

\section{Average Capacity Utilization rates in Nigeria's manufacturing sector (1989-2009)}

\begin{tabular}{|l|l|l|}
\hline Year & Average Capacity Utilization Rates $(\%)$ & Percentage Change in the Rate \\
\hline 1989 & 43.80 & - \\
\hline 1990 & 40.30 & -8.0 \\
\hline 1991 & 42.00 & 4.2 \\
\hline 1992 & 38.10 & -9.3 \\
\hline 1993 & 37.20 & -2.3 \\
\hline 1994 & 30.40 & -18.3 \\
\hline 1995 & 29.30 & -3.6 \\
\hline 1996 & 32.50 & 10.9 \\
\hline 1997 & 30.40 & -6.5 \\
\hline 1998 & 30.30 & -0.3 \\
\hline 1999 & 34.40 & 13.2 \\
\hline 2000 & 33.40 & -4.0 \\
\hline 2001 & 30.30 & -2.6 \\
\hline 2002 & 28.00 & -3.8 \\
\hline 2003 & 34.30 & 12.6 \\
\hline 2004 & 32.00 & -6.9 \\
\hline 2005 & 31.00 & -5.1 \\
\hline 2006 & 27.20 & -2.9 \\
\hline 2007 & 27.56 & -3.0 \\
\hline 2008 & 28.00 & -3.8 \\
\hline 2009 & 30.30 & -4.2 \\
\hline
\end{tabular}

Annual average capacity utilization $=-2.01 \%$

Capacity utilization rates in the manufacturing sector declined with an annual average rate of about $2 \%$ between 1989 and 2009. In absolute terms, capacity utilization rates decreased from $43.8 \%$ in 1989 to $30.80 \%$ in 2009 .

Specifically, utilization rate decreased between 1989 and 1991 from a rate of $43.8 \%$ to $42.3 \%$ in 1990 and increased to $42 \%$ in 1991 . This later took a plunge in the preceding years by $-93 \%$, infrastructure work such as privatization, further ports reform and the removal of other bottlenecks to investment.

In a matter of resources allocation of fresh capacity and that of utilization of existing capacity in different sections of the economy.

In industries, studies reveal the existing of a good deal of unutilized revealed that there exists considerable wile capacity in different industries.

Therefore, while planning in output and employment, the planning authority can take stock of the idle capacity available in -different sections and in the event of their availability, resources allocation of these sectors can be appropriately reduced and the resources so available diverted to uses. 


\subsection{Structural Flow Of Capital In The Nigeria Manufacturing Sector}

Here, we investigate the trends in capital formation in Nigeria (manufacturing sector).

The table above from the annual abstracts of a statistics shows the composition of gross fixed formation at current purchases value in Nigeria between 1989 and ' QQ

From the table, capital formation grew at an annual average rate of 33.2 percent between 1989 and 2009.

Starting from \#18424.09 million in 2008, capital stock grew to \#489596.88 million in 2009. This represented a nine-fold increase in capital.

In absolute terms, capital stock increased between 1989 and 1990 from \# 18424.09 million to \#31126.83 million representing a $68.9 \%$ increase.

Between 1990 and 1991, capital stock further increase at a decreasing rate of $14.4 \%$, that is. \#35623.85 million.

In 1992, capital stock increased to \#58,940.28 million that is 65.5 percent increase 1993, capital increased to \#81,398.07 million; that is, 38.1 percent increase. This increase in capital stock shows that it is increasing at a decreasing rate compared to the latter year capital stock.

Furthermore, in 1994, capital stock increases to \#85314.39 million representing a 4.8 percent increase. This shows that capital stock for the year 1994 is increasing at a decreasing rate.

However, in 1995, capital stock increased to \#114, 827.29 million; that is, 34.6 percent increase.

In 1996 and 1999, capital stock increased to \#172,491.80 million, that is 50.3 percent increase \#250.000.94 million (50.2) percent increase respectively.

Finally, from 1998 to 2009 in 1998, capital stock increased to \#502,341.00 million, that is 13.3 percent increase. This showed that capital stock increased at a decreasing rate compared with the latter year result on capital stock.

The increase in capital stock over the year is not effective enough to necessitate the required full economic development and growth in output.

At this juncture, it is pertinent to observe the growth of capital functions in the manufacturing sector by evaluating the contribution of plant equipment and machinery to capital formation in the Nigerian economy.

According to the 'National Accounts or Nigeria (1989-2009), a table on percentage contribution of plant, equipment and machinery to gross capital formation at current purchases value to plant and equipment can be shown as follows: Percentage contribution of plant, equipment and machinery to gross capital formation a current value (1989-2009).

\begin{tabular}{|l|l|l|}
\hline Year & $\begin{array}{l}\text { Plant, Equip, Machinery (\%) contribution to } \\
\text { GCE }\end{array}$ & $\begin{array}{l}\text { Percentage Change } \\
\text { Contribution }\end{array}$ \\
\hline 1989 & 41.99 & - \\
\hline 1990 & 46.09 & 9.8 \\
\hline 1991 & 49.52 & 7.4 \\
\hline 1992 & 54.82 & 10.7 \\
\hline 1993 & 55.58 & 1.4 \\
\hline 1994 & 52.20 & -6.1 \\
\hline 1995 & 50.81 & -2.7 \\
\hline 1996 & 57.45 & 13.1 \\
\hline 1997 & 49.54 & 13.8 \\
\hline 1998 & 49.41 & -0.3 \\
\hline 1999 & 53.22 & 4.6 \\
\hline 2000 & 54.28 & -3.5 \\
\hline 2001 & 61.33 & 8.6 \\
\hline 2002 & 63.44 & 9.4 \\
\hline 2003 & 65.88 & 3.8 \\
\hline 2004 & 62.44 & 9.4 \\
\hline 2005 & 64.46 & -2.4 \\
\hline 2006 & 65.88 & 9.3 \\
\hline 2007 & 67.36 & 8.4 \\
\hline 2008 & 65.42 & 7.1 \\
\hline 2009 & 66.24 & 8.2 \\
\hline
\end{tabular}

Manufacturing sector dominated the capital stock- in the sense that the amount of plant equipment in the distribution of capital function was more compared to over components of capital formation distribution.

The percentage contribution in capital formation grew at an advantage rate of $2.2 \%$ between 1989 and 2009 .

In the absolute term, the percentage contribution of plant, equipment and machinery formation increased from $41.99 \%$ in 1989 to 66.24 in 2009. 
Specifically, percentage contribution of plant and machinery is capital formation increased from $41.99 \%$ in $1989,46.0 \%$ in 1990 it further increased to $49.52 \%$ of gross capital formation in 1991.

Also in 1992 and 1993, contribution of plant and machinery to capital formation increased to 54.82\% and $55.58 \%$ respectively.

However, in 1994 and 1995, the contribution of plant and equipment to capital formation declined by $-6.1 \%$ and $-2.7 \%$ respectively.

In 1996, percentage contribution increased to 51,455.00. Finally, in 1997 to 1998 , the percentage contribution of plant, equipment and machinery to gross formation declined by $-13.8 \%$ and $7.1 \%$ respectively. What is worth noting here is the fast growth of capital formation in this sector over the period under survey.

Obviously, this indicated that the industrial base of Nigerian economy is relatively strong however; the rate of growth of plant machinery and equipment in capital formation needs to be improved upon.

In conclusion, the relatively strong industrial base of Nigeria will in turn crate a momentum for the economy via the generation of increased output and employment.

\subsection{Credit Creation And Its Trend In The Nigerian Manufacturing Sector}

The necessary capital or credit allocation needed for investment and capital formation can be obtained or generated from various sources which may include; merchant banks, and commercial banks and foreign private investment etc.

It should be noted that these sources have a vital impart on the creation of resources for capital formation in Nigeria manufacturing sector.

Merchant Bank

They provide short medium and long-terms loans; accept large deposit, bills and deals in stock. They also deal in the financial of industrial and related project as well as foreign transaction. Thus the merchant banks also provide reliable resources needed for generating capital in the Nigerian manufacturing sector.

By looking at the annual abstracts by the Central Bank of Nigeria, the distribution of merchant banks loan and advances to the manufacturing and processed sector can be described as follow:

Merchant Banks loan and advances to the processed sector

\begin{tabular}{|l|l|l|}
\hline Year & Loan and advance N' Million & $\begin{array}{l}\text { Percentage Change } \\
\text { in loan \& advance }\end{array}$ \\
\hline 1989 & $2,520.5$ & - \\
\hline 1990 & $3,091.4$ & 22.7 \\
\hline 1991 & 4543.1 & 47.0 \\
\hline 1992 & 5777.4 & 27.2 \\
\hline 1993 & 8863.6 & 53.4 \\
\hline 1994 & 10000.3 & 12.8 \\
\hline 1995 & 13653.6 & 36.5 \\
\hline 1996 & 14979.8 & 8.4 \\
\hline 1997 & 19361.3 & 30.8 \\
\hline 1998 & 32299.8 & 66.8 \\
\hline 1999 & 39124.6 & 21.2 \\
\hline 2000 & 44378.1 & 14.6 \\
\hline 2001 & 47861.5 & 13.5 \\
\hline 2002 & 48131.9 & 7.2 \\
\hline 2003 & 53208.6 & 9.0 \\
\hline 2004 & 54443.2 & 8.7 \\
\hline 2005 & 59541.1 & 10.5 \\
\hline 2006 & 67168.3 & 72.1 \\
\hline 2007 & 68325.7 & 20.1 \\
\hline 2008 & 80013.0 & 78.1 \\
\hline 2009 & 85341.8 & 60.0 \\
\hline
\end{tabular}

The distribution of loan and advances by the merchant banks to the Nigerian manufacturing sector increased at an average rate of about $34 \%$ between 1989 and 2009.

In absolute terms, distribution of loans and advances by merchant bank to the processed sector increased from \#2520.5 million in 1989 to \#80,013.0 in 2009. Specifically, merchant banks distribution of loans and advances to the manufacturing sector increased between 1989 and 1990 from \#2520 million to \#3091.4 million (that is, $22.7 \%$ increase). In 1991, there was a substantial increase in the distribution of loans and advances to \#453.1 million which signified a $47 \%$ increase in allocation lies compared to the latter year's results. 
However, the year 1992 recorded that distribution of loan and advances, by the merchant banks to the processed sector, increased at a decreasing rate of $27.2 \%$ which represented \#5777.4 million.

Also, in 1993, the distribution of loans and advances by the merchant banks to the processed sector increased by $53.4 \%$ which in absolute terms was \#8863.6 million. In 1994, there was an increase of loans and advances at a decreasing rate of $12.8 \%$, to the processed sector. This in absolute terms was \#10000.3 million in the year 1995; the contribution of merchant bank loans and advances to the processed term was \#13653.6 million.

However, in 1996, loan and advances by merchant bank to the processed sector, increased at a decreasing rate $8.4 \%$ which absolutely represent \#14797.8 million. Furthermore, in 1997, the distribution of merchant bank loan and advances to the processed sector increased by $30.8 \%$ which absolutely represented \#1361.3 million.

However, in 1998, the distribution of loans and advances by merchant banks to processed or manufacturing sector increased by $66.8 \%$ which absolutely represented\#32299.8 million

From 1999 to 2002, the distribution of loan and advance by merchant bank decreased by $21,2 \%, 14.6 \%, 13.5 \%$, 7.2\% which represent \#39124.6, \#44378.1, \#47861.5, and \#48131.9\%.

Also in 2003, there was an increase of $9.0 \%$ which represent \#53208.6. Therefore was an unstable distribution from 2004 to 2009.

In addition, the changing value of merchant banks loan and advances to the processed sector can be diagrammatically represented by a graph or chart which can be shown as follows.

In conclusion, the changing value of merchant bank's loan and advances to the processed sector can attribute to the changing or varying lending rates charged for the different period and the changes in the monetary and investment policy embarked upon by monetary authorities.

Commercial Banks

They accept deposits, safe-custody of valuables, lending of money, agent of payment, discounting bills of exchange and other miscellaneous function. Thus the commercial banks greats credit through the process of making it possible for more deposits to be made through loans.

By looking at the criminal abstract of statistics by the Central Bank of Nigeria, the distribution of commercial banks loan and advances to the processed sector can be described as follows:

Commercial Bank's loan and advances to the processed sector

\begin{tabular}{|l|l|l|}
\hline Year & Loan and advance N' Million & Percentage Change loans and advance (\%) \\
\hline 1989 & 6671.7 & - \\
\hline 1990 & 7883.7 & 18.2 \\
\hline 1991 & 10911.3 & 38.4 \\
\hline 1992 & 15403.9 & 41.2 \\
\hline 1993 & 23110.6 & 50 \\
\hline 1994 & 39390.8 & 70.4 \\
\hline 1995 & 58090.7 & 47.4 \\
\hline 1996 & 72238.1 & 24.4 \\
\hline 1997 & 82823.1 & 14.7 \\
\hline 1998 & 96732.7 & 16.7 \\
\hline 1999 & 101712.1 & 15.4 \\
\hline 2000 & 115614.9 & 13.7 \\
\hline 2001 & 135614.9 & 13.7 \\
\hline 2002 & 182414.7 & 30.8 \\
\hline 2003 & 202131.8 & 19.9 \\
\hline 2004 & 220961.0 & 15.0 \\
\hline 2005 & 254176.4 & 29.4 \\
\hline 2006 & 278113.2 & 38.1 \\
\hline 2007 & 299169.5 & 23.6 \\
\hline 2008 & 320141.4 & 17.9 \\
\hline 2009 & 346311.0 & 30.2 \\
\hline
\end{tabular}

The distribution of loan and advances by the commercial banks to the Nigerian manufacturing sector increased at an annual average rate of $35.7 \%$ between 1989 to 2009 .

In absolute terms, distribution of loans and advances to the manufacturing sectors increased between 1989 and 1990 from \#6671.7 million to \#7883.7 million in 1990 (that is $18.2 \%$ increase). 
In 1991, there was a substantial increase in the distribution of loans and advances to the processed sector by $38.4 \%$ which in absolute term was \#10911.3 million.

In addition, the year 1992 recorded a more proportionate increase in the distribution of loans and advances to the processed sector by $41.2 \%$ which absolutely represented \#15403.9 million.

Also, in 1993, the distribution of loan and advances by commercial bank to the processed sector increased by $50 \%$ which in absolute term represented \#3930.8 million.

Furthermore, in 1994, there was an increase of distribution of loans and advances to the manufacturing sector at an increasing rate of $70.4 \%$ which in absolute terms represented \#3930.8 million

However, in 1995, the distribution of loans and advances to the processed sector increased at a decreasing rate of $47.5 \%$ which absolutely represented \#58090.7 million.

In addition, in 1996 and 1997, the contribution of loans and advances by commercial banks to the processed sector increased at decreasing rate of $24.4 \%$ and $14.7 \%$, which in absolute terms was \#7223.1 million and \#82823.1 million respectively.

Finally, in 1998, the distribution of loans and advances by commercial banks to the processed sector increased by a rate of $16.8 \%$ which absolutely represented \#96737.7 million.

Thus, the distribution of commercial banks loan and advances can also be diagrammatically by a chart which is shown as follows.

The activities of the commercial banks in their sectorial allocation of loan and advances to the manufacturing sector have increased proportionate.

However, the effects of varying lending rate (interest) have affected the value for various periods.

Foreign Private Investment

The role of private investment and foreign and in capital formation in particular and economic development in general, can be quite substantial. They can for instance, increase or trigger off indigenous capital formation by accelerating domestic demand.

The can make free foreign exchange available for consumer good imports thereby removing the balance of payment constraints to mobilization of existing local resources.

By looking at the Central Bank bulletin for December 1998, the total cumulative distribution of foreign private investment to the manufacturing and processing sector for can be described as follows:

\begin{tabular}{|l|l|l|}
\hline Year & Foreign private investment total (N'000) & $\begin{array}{l}\text { Percent change in foreign investment } \\
(\%)\end{array}$ \\
\hline 1989 & $5,436,637.0$ & - \\
\hline 1990 & $6,488,636.0$ & 19.4 \\
\hline 1991 & $8,754,568.0$ & 34.9 \\
\hline 1992 & $10,183,734.0$ & 16.3 \\
\hline 1993 & $13,314,526.0$ & 30.7 \\
\hline 1994 & $14,489,130.0$ & 8.8 \\
\hline 1995 & $30,776,990.0$ & 112.4 \\
\hline 1996 & $33,258,127.0$ & 8.1 \\
\hline 1997 & $34,251,481.0$ & 3 \\
\hline
\end{tabular}

From the table, the foreign private investment increased at an annual average rate of $29.2 \%$ between 1989 and 1997.

In the absolute term, the foreign investment increased from \#5,436,637.000 in 1989 to \#34,251,481.000 in 1997. Specifically, the private foreign investment increased between years 1989, 1990 and 1991 to \#5,436.637 million, $\# 6,488,636$ million and \#8,654,568 million respectively.

However, in 1993, the foreign private investment to the processed sector increase at a decreasing rate of $16.3 \%$ which in absolute terms was \#10,183,742 million.

In 1993, foreign private investment to the processed sector increased by $30.7 \%$ which is absolute terms was \#13,314,526 million.

In 1994, the foreign private investment to the processed sector increase at a decreasing rate of $8.8 \%$ which absolutely represented \#14,489.130 million.

Furthermore, in 1995, the foreign private investment is the processed sector increased substantially by $112.4 \%$ which in absolute terms was \#30,776.990 million.

Finally, is 1996 and 1997, the foreign private investment to the processed sector increased at a decreasing rate of $8.1 \%$ and $3 \%$ respectively. This is absolute terms respectively \#33,258.127 million in 1996 and \#34,251.451 million in 1997. 


\section{Model Specification and Empirical Results}

We employ Ordinary Least Square (OLS) method of analysis to examine the relationship between real ACUR and other variables in our study.

Model Specification

In order to empirically determine the impact of these variables on the capacity utilization, the multiple regression equation is explicitly specified in functional form as follows:

ACUR $=\mathrm{f}(\mathrm{GCF}, \mathrm{GDP}, \mathrm{MANUF}, \mathrm{PDSTR})$

Where ACUR =Average Capacity Utilisation is dependent variable

Definition of terms

GCF $=$ Gross Capital Formation

GDP $=$ Gross Domestic Product

MANUF $=$ Manufacturing

PDSTR $=$ percentage distribution (manufaturing)

Equation 1 can be specifically expressed in explicit econometric form as follows:

ACUR $=\alpha 0+\alpha 1$ GCF $+\alpha 2$ GDP $+\alpha 3$ MANUF $+\alpha 4$ PDSTR + Ut.

Where $\mathrm{U}$ is stochastic or random error term (with usual properties of zero mean and non-serial correlation).

$\alpha 1-\alpha 4=\quad$ Co-efficient of associated variables

$\alpha 0=$ Constant Intercept.

Data Analysis and Findings

OLS Regression Results

The Estimated Model for this research study is given below:

ACUR $=-0.147541252368 * \mathrm{GCF}+0.0265267738771 * \mathrm{GDP}+0.00236745783113 *$ MANUF $0.0205989451367 *$ PDSTR +4.90401279594

The Table below shows the analysis of the result of the data used in the study. The method of analysis employed is the Ordinary Least Square (OLS).

Table 1: OLS Regression Result

\begin{tabular}{lllll}
\hline \hline Variable & Coefficient & Std. Error & t-Statistic & Prob. \\
\hline \hline GCF & $-0.147541 * *$ & 0.050611 & -2.915193 & 0.0101 \\
GDP & 0.026527 & 0.031246 & 0.848954 & 0.4084 \\
MANUF & 0.002367 & 0.027901 & 0.084851 & 0.9334 \\
PDSTR & -0.020599 & 0.136183 & -0.151259 & 0.8817 \\
C & 4.904013 & 0.361411 & 13.56906 & 0.0000 \\
\hline \hline
\end{tabular}

R2 = 0.693019; Adj. R2 = 0.616274; F-statistics = 9.030121; Prob(F-statistic $)=0.000516 ;$ DWstat $=1.341663 ;$

Source: Author's computation

Note: $* * *=$ significant at $1 \% ; * *=$ significant at $5 \%$ and $*=$ significant at $10 \%$

The result of estimation of the model summarized in the table above shows that there is a positive relationship between Capacity Utilization and GDP and manufacturing. However, Gross capital formation and percentage distribution are negatively related to capacity utilization. Furthermore, a closer look at the result shows that Gross Capital Formation is statistically significant at 5 percent. The R-squared which is the coefficient of determination, shows the percentage of variation in the dependent variable that was accounted for by variations in the explanatory variables. It measures the explanatory powers of the model. It is usually between zero and one. A close inspection of the table above indicates that the specified model has a fairly high coefficient of determination. This can be seen from R-squared of 69 per cent. The R-squared reports that the variables can explain about 69 per cent of total variation in average capacity utilization rate, the remaining 31 per cent variation in the average capacity utilization rate is not accounted for in the model or rather accounted for by other variables outside the model. The fitness of every regression result is based on its R-squared. The adjusted R-squared shows that asymptotically, the variables can explain approximately 62 per cent of total variation. The implication of this is that the model has goodness of fit. F-statistics test the overall significance of the model under study. F-calculated is compared with F-tabulated where F- cal is greater than F-tab we reject the null hypothesis (Ho) and conclude that the variable is statistically significant in explaining the dependent variable. From the table, it shows that F-statistics is 9.030121; and Prob (F-statistic) is 0.000516 . We, therefore, reject null hypothesis and accept alternative hypothesis. This is because it is greater than the critical values of 2.57 and 3.79 at $1 \%$ and $5 \%$ respectively. Thus, it implies that the model under this study is statistically 
significantly different from zero. In other words, the explanatory variables jointly considered are significantly important in explaining variation in the dependent variable - average capacity utilization rate Durbin - Watson Statistic is given as 1.341663 which free the model from autocorrelation.

\section{Unit Root Test Result}

Literature has established that most time series variables are not stationary. Therefore, using nonstationary variables in the model might lead to spurious regression which cannot be used for precise prediction. (Gujarati, 2003). Hence, our first step is to examine the characteristics of the time series data used for estimation of the model to determine whether the variables have unit roots, that is, whether it is stationary and the order of integration. The Augmented Dickey-Fuller test is used for this purpose. A variable is considered stationary if the absolute ADF value is higher than any of the absolute Mackinnon values. The test is conducted with intercept term.

Table 2: Unit Root Test Summary Statistics (Augmented Dickey Fuller)

\begin{tabular}{|c|c|c|c|c|c|}
\hline \multirow[b]{2}{*}{ Variables } & \multicolumn{2}{|c|}{ ADF Test Statistics } & \multicolumn{2}{|c|}{ Critical Values (5\%) } & \multirow{2}{*}{$\begin{array}{l}\text { Order of } \\
\text { Integration }\end{array}$} \\
\hline & Level & 1st Difference & Level & 1st Difference & \\
\hline ACUR & -2.461838 & -4.813290 & -3.020686 & -3.029970 & $\mathrm{I}(1)$ \\
\hline GCF & -4.008453 & -3.171446 & -3.040391 & -3.029970 & $\mathrm{I}(0)$ \\
\hline GDP & -3.244920 & -8.295521 & -3.065585 & -3.029970 & $\mathrm{I}(0)$ \\
\hline MANUF & -1.980588 & -3.973943 & -3.020686 & -3.029970 & $\mathrm{I}(1)$ \\
\hline PDSTR & -3.027081 & -4.787404 & -3.020686 & -3.040391 & $\mathrm{I}(0)$ \\
\hline
\end{tabular}

Source: Author's computation

From the table above the results clearly shows that average capacity utilization and manufacturing index are stationary at level. Meanwhile, gross fixed capital formation, reel gross domestic product and percentage distribution are non-stationary. This suggests the need to difference the series to obtain stationarity. At first difference, however these variables are integrated of the same order.

\section{Co-integration test results}

Co-integration analysis is carried out to determine the existence of long-run relationship that exists between the dependent variable and its regressor. When one or all of the variables is/are non-stationary at level which means they have stochastic trend. Essentially, it is used to check if the independent variables can predict the dependent variable now (short-run) or in the future (long-run). The long run relationships among the variables were examined using Johasen (1991) co-integration framework. The co-integration result is presented in table 3 below:

Table 3: Unrestricted Co-integration Rank Test(Trace)

\begin{tabular}{ccccc}
\hline \hline $\begin{array}{c}\text { Hypothesized } \\
\text { No. of CE(s) }\end{array}$ & Eigenvalue & $\begin{array}{c}\text { Trace } \\
\text { Statistic }\end{array}$ & $\begin{array}{c}0.05 \\
\text { Critical Value }\end{array}$ & Prob.** \\
\hline \hline None ${ }^{*}$ & 0.848912 & 91.18862 & 69.81889 & 0.0004 \\
At most 1 & 0.774012 & 55.28069 & 47.85613 & 0.0086 \\
At most 2 & 0.578273 & 27.02251 & 29.79707 & 0.1011 \\
At most 3 & 0.311015 & 10.61797 & 15.49471 & 0.2361 \\
At most 4 & 0.169980 & 3.539804 & 3.841466 & 0.0599 \\
\hline \hline
\end{tabular}

Trace test indicates 2 co-integrating eqn(s) at the 0.05 level

* denotes rejection of the hypothesis at the 0.05 level

**MacKinnon-Haug-Michelis (1999) p-values

Unrestricted Cointegration Rank Test (Maximum Eigenvalue)

\begin{tabular}{ccccc}
\hline \hline $\begin{array}{c}\text { Hypothesized } \\
\text { No. of CE(s) }\end{array}$ & Eigenvalue & $\begin{array}{c}\text { Max-Eigen } \\
\text { Statistic }\end{array}$ & $\begin{array}{c}0.05 \\
\text { Critical Value }\end{array}$ & Prob.** \\
\hline \hline None * & 0.848912 & 35.90793 & 33.87687 & 0.0282 \\
At most 1 * & 0.774012 & 28.25818 & 27.58434 & 0.0410 \\
At most 2 & 0.578273 & 16.40454 & 21.13162 & 0.2021 \\
At most 3 & 0.311015 & 7.078167 & 14.26460 & 0.4799
\end{tabular}



At most 4
0.169980
3.539804
3.841466
0.0599

Max-eigenvalue test indicates 2 cointegrating eqn(s) at the 0.05 level

$*$ denotes rejection of the hypothesis at the 0.05 level

**MacKinnon-Haug-Michelis (1999) p-values

The table above shows the result of the co-integration analysis conducted on the variables in our study. The result reveals that both trace test and Max-eigen value test indicate that at least one co-integrating vector in the equation. This implies there is a long run relationship among the variables (both dependent and independent). In essence, these variables will converge to equilibrium point in the long run.

\section{Granger causality test}

In order to examine the Granger causal relationships between the variables under examination we used the estimated model in the previous section. F statistic was used as a testing criterion. The results relating to the existence of Granger causal relationships between the variables are presented in table 4 below.

Table 4: Granger causality tests

\begin{tabular}{|l|l|l|l|}
\hline $\begin{array}{l}\text { Dependent } \\
\text { Variable }\end{array}$ & Testing Hypothesis & F1 & F2 \\
\hline \multirow{4}{*}{ ACUR } & $\begin{array}{l}\text { GCF- there is a unidirectional relationship } \\
(\text { ACUR } \Leftarrow \text { GCF) }\end{array}$ & 1.37126 & 2.65286 \\
\cline { 2 - 4 } & MANUF- there is no causality (ACUR \#MANUF) & 1.30626 & 0.34702 \\
\cline { 2 - 4 } & PDSTR- there is no causality (ACUR \# PDSTR) & 0.23925 & 0.54713 \\
\cline { 2 - 4 } & GDP - there is a bidirectional relationship (ACUR $\Leftrightarrow$ GDP) & 2.96292 & 4.14861 \\
\hline
\end{tabular}

Source: Author's computation

From Granger causality tests in table 3 above, we can infer that: there is a unidirectional causal relationship between the gross capital formation and capacity utilization with direction from gross capital formation. The test shows that there is bidirectional causal relationship between gross fixed capital formation and gross domestic product.

Meanwhile, there is no causal relationship between capacity utilization and the percentage distribution of manufacturing, and also with manufacturing index.

\section{Summary, Conclusion And Recommendations}

The objective of the study was to examine the linkage between of between gross fixed capital formation and average capacity utilization rate. Our main findings are as follows:

First, we find out by testing for stationary of the data used through the unit not process, that there is an existence of a unidirectional causal relationship between gross fixed capital formation and average capacity utilization rate with direction from gross fixed capital formation.

The test also revealed that there is a bidirectional causal relationship between average capacity utilization rate and gross domestic product. Meanwhile, there is no existence of causality relationship between average capacity utilization rate and the percentage distribution.

Conclusively, our findings suggest in clear terms that manufacturing sector performance, which was measured by average capacity utilization rate could only be improved if the government can increase capital formation via commercial banks increased interest rate that will mobilize savings and consequently increase the domestic output. It can be inferred that the overall measure of capital formation will act as a major determinant of manufacturing sector in Nigeria.

\section{References}

[1] Beddies, C. (1999), - Investment, Capital Accumulation and Growth: Some Evidence from Gambia: 1964-1998. IMF Working Paper 99/117, August.

[2] Ben-David, D. (1998), - Convergence Clubs and Subsistence Economies , Journal of Development Economics, 55, pp.155-171.

[3] Chibber, A. and D. Mansoor (1990), -Fiscal policy and private investment in developing countries . Recherche Economique, XLIV, Numero 2-3.

[4] Easterly, W. and R. Levine (1997), -Africa's Growth Tragedy: Policies and Ethnic Divisions, Quarterly Journal of Economics, 112 , November, pp.1203-50

[5] Collier, P. and J.W. Gunning (1999), -Explaining African Economic Performance, Journal of Economic Literature, 37, March, pp.64- 111

[6] Ghura, D. and T. Hadji Michael (1996), - Growth in Sub-Saharan Africa, Staff Papers, International Monetary Fund, 43, September. 
[7] Ghura, D. (1997), - Private Investment and Endogenous Growth: Evidence from Cameroon , IMF Working Paper 97/165, December.

[8] Galbis, V. (1979), - Money, Investment, and Growth in Latin America , Economic Development and Cultural Change

[9] Gillis, M., D. W. Perkins, M. Roemer and D. R. Snodgrass. (1987), Economics of Development, Second Edition. -:w.w. Norton.

[10] Herandez-Cata, E. (2000), -Raising Growth and Investment in Sub-Saharan Africa: What Can be Done? Policy Discussion Paper: PDP/00/4, International Monetary Fund, Washington, D .C.

[11] Kouassy, O. and B. Bohoun, (2010) -Consequences and limitations of recent fiscal policy in Côte d'Ivoire . Report on Research sponsored by AERC, Nairobi, Kenya.

[12] Khan, M.S., and C.M. Reinhart (1990), - Private Investment and Economic Growth in Developing Countries, World Development, 18 (1), pp. 19-27

[13] McKinnon, R.I. (1973), - Money and Capital in Economic Development”. Washington D.C. Far East Journal of Psychology and Business Vol 3 No 1 April 201124

[14] Ndikumana, L. (2000), - Financial Determinants of Domestic Investment in Sub-Saharan Africa, World Development, 28 (2), pp.381-400.

[15] Shaw, E.S. (1973), - Financial Deepening in Economic Development. New York: Oxford University Press.

[16] Yotopoulos, P. and J. Nugent. (1976), —Economics of Development: Empirical Investigations, New York: Harper and Row.

[17] Yaw Asante (2000). - Determinants of private investment behavior-AERC Research Paper 100 African Economic Research Consortium, Nairobi March 2000 